\title{
Rilievo e documentazione del museo Tesla a Zagabria per la valorizzazione mediante applicazioni di AR e VR
}

\author{
Marco Medici \\ Federico Ferrari
}

Abstract

Il paper presenta l'esperienza di rilievo, documentazione e valorizzazione del museo Tesla a Zagabria. Per il rilievo del complesso architettonico si è utilizzata una metodologia ibrida, oggi consolidata, che si awale di laser scanner integrata a tecniche di fotogrammetria, sia aerea che terrestre per il dettaglio di manufatti. I dati raccolti sono serviti da base per la realizzazione di modelli BIM-based di tipo architettonico e strutturale, poi arricchiti mediante le tecnologie offerte dalla piattaforma INCEPTION al fine di aggregare l'ulteriore documentazione raccolta verso la creazione di modelli H-BIM. Questi ultimi hanno poi permesso il loro sfruttamento, mediante opportune ottimizzazioni, in ambienti immersivi di realtà virtuale e aumentata per la fruizione del valore dell'opera architettonica e dei manufatti qui contenuti.
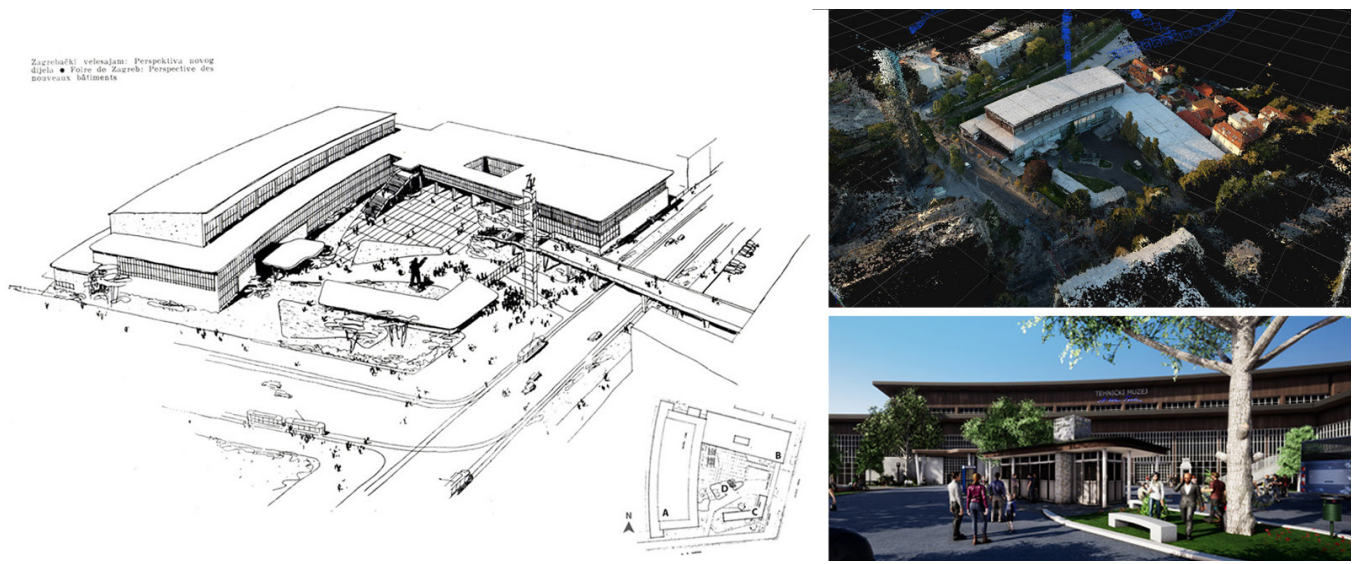


\section{Inquadramento e ambito di indagine}

Il rilievo, la documentazione e la valorizzazione degli spazi e dell'allestimento del museo Tesla a Zagabria (TMNT) si inquadra nell'ambito dei casi studio del progetto INCEPTION [I], con l'obiettivo di potenziare e sviluppare strumenti comunicativi da utilizzare all'interno del museo, per poter rafforzare la comprensione del percorso museale e del ruolo del museo nello sviluppo economico, urbanistico e storico-politico della ex-Jugoslavia.

A tal fine, la piattaforma INCEPTION è stata utilizzata come elemento aggregatore di tutte le informazioni specifiche, tramite modelli 3D BIM-based, utilizzati a verifica e per l'analisi strutturale dell'edificio (modello FEM), come ausilio alle strategie di decision making in termini manutentivi e per applicazioni web-mobile di realtà virtuale (VR) o aumentata (AR) a scopo turistico-informativo, divulgativo e marketing culturale.

La storia del complesso

Il complesso nel quale il museo Tesla si inserisce oggi (fig. I), noto in origine come l'Assemblea di Zagabria su via Savska, è stato realizzato sulla base di un progetto di Marijan Haberle e Hinko Bauer, già quasi integralmente completato nel 1939.

Dal 1909, con una serie di padiglioni, realizzati come sede di eventi fieristici, Zagabria si arricchisce di strutture architettoniche di interesse, tra cui spicca il padiglione francese.

Dopo la Prima Guerra Mondiale, è evidente come l'area dell'Assemblea sia utilizzata come strumento di diplomazia culturale, con l'obiettivo di comprovare la capacità e la forza economica della neo-Jugoslavia.

In tal senso nel 1946 la zona dell'Assemblea viene rinominata Fiera di Zagabria [Vranić 2020] e viene presa la decisione di ampliare i 13.400 mq di spazi espositivi, rivelatisi insufficienti.

Nel 1949, in 8 mesi, l'architetto Marijan Haberle realizza nuovi padiglioni per 8.000 mq, al 39 di via Savska di fronte al nucleo originario, oggi Centro Studentesco (fig. 2). L'edificio principale, che va a sostituire un deposito di tram, presenta un'innovativa struttura portante in legno.

Fig. I. Vista aerea del complesso dell'area dell'Ex Fiera di Zagabria realizzato sulla base del progetto di Marijan Haberle e Hinko Bauer. Si evidenziano il padiglione Francese, il centro studentesco e II Museo Tesla. Nella immagine in basso la "piazza" di ingresso al Museo con indicati quattro padiglioni.

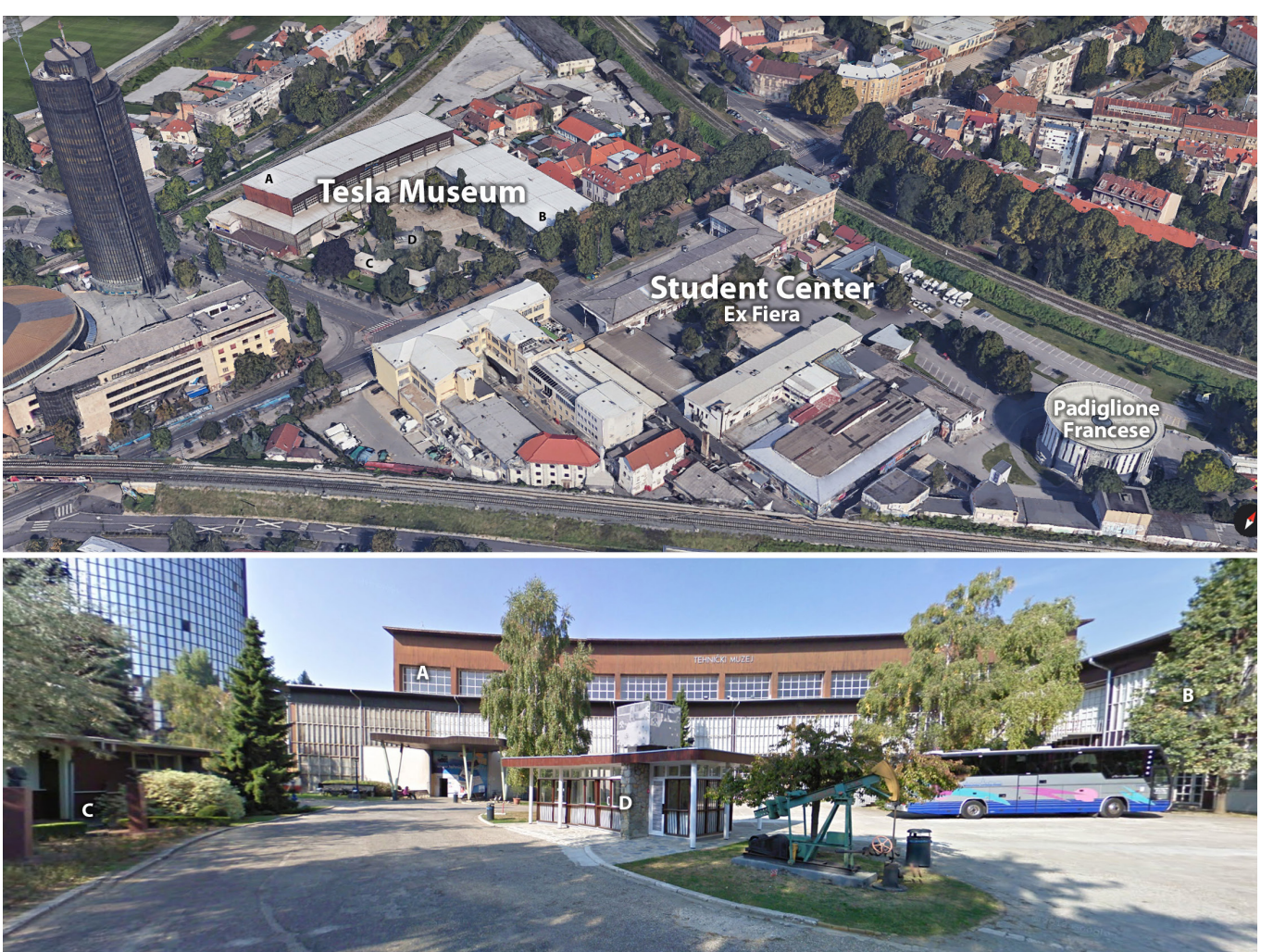


Fig. 2. Disegni e foto storiche del Museo, tra cui quella del giorno d naugurazione.

Vella prospettiva è da notare il ponte prefabbricato in acciaio per l'attraversamento di via Savska (come collegamento alla ExFiera) e la colonna verticale di 30 metri in tubi d'acciaio entrambi mai realizzati. In ritmo de prospetti è evidenziato dall serialità del modulo tilizzato dal progettista.
La struttura più grande (padiglioni $A$ e $B$ ), con una disposizione a $L$ parzialmente curva, viene posizionata in profondità, mentre il un altro padiglione chiude l'incrocio (padiglione C) realizzando una piazza come accesso e ponendo all'interno un altro piccolo padiglione (D). Un ponte prefabbricato per attraversare via Savska (collegamento alla parte vecchia) e una colonna verticale di 30 metri, con rilevanza urbanistica e una declinazione pubblicitario-commerciale, avrebbero dovuto completare il progetto ma non furono realizzati.

Dopo il 1950 questi ultimi padiglioni vengono trasformati in Museo della Scienza e della Tecnica quando la Fiera viene pienamente rifunzionalizzata a carattere commerciale, a seguito del ruolo dell'Unione Sovietica come nuovo e principale partner politico-economico. Più precisamente, dal 1954 al 1959 la Fiera viene trasferita in una nuova sede, mentre il museo viene inaugurato ufficialmente nel 1963 e dal 2015 è intitolato a Nikola Tesla [2].
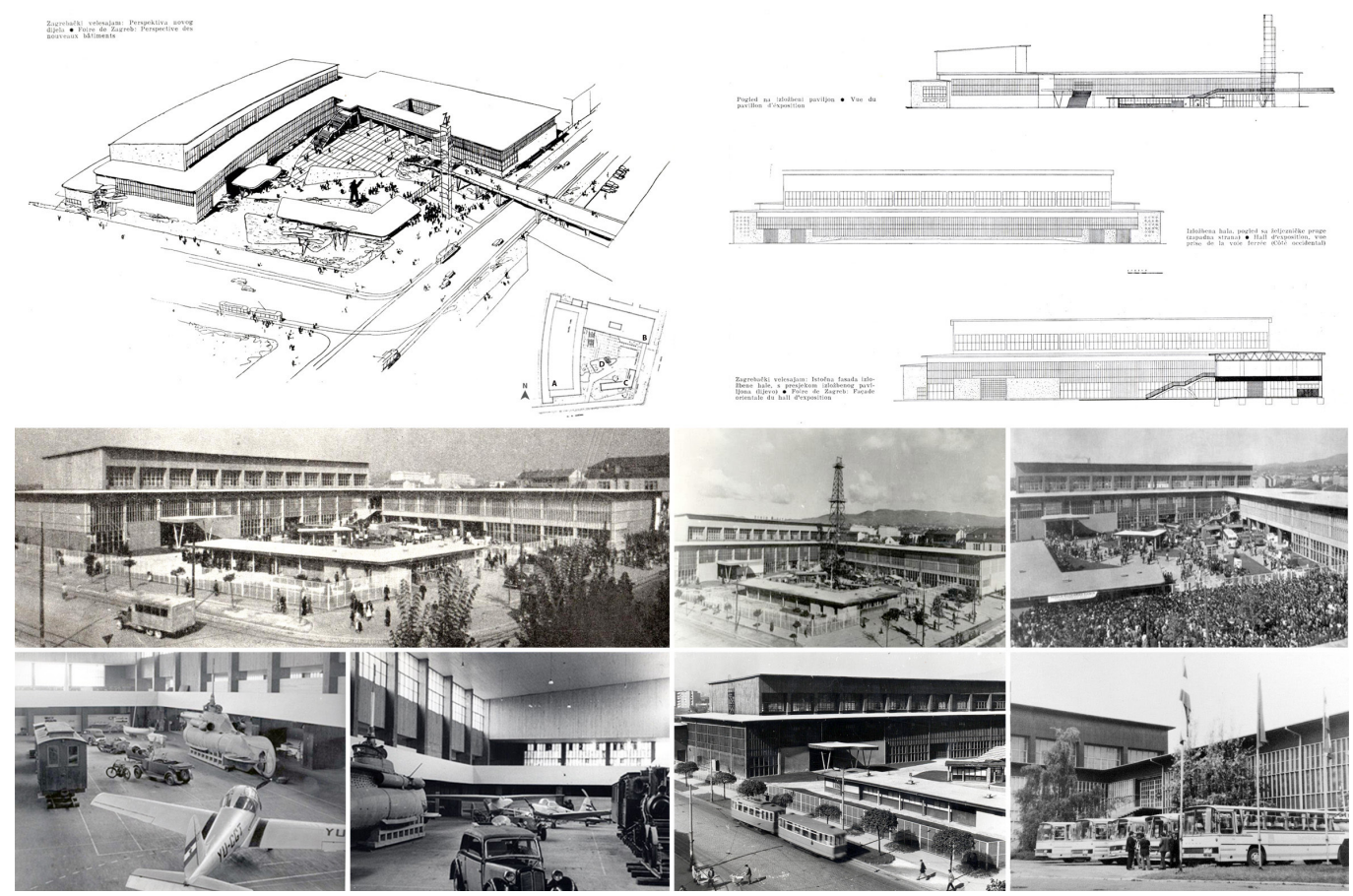

La struttura portante del museo: caratteristiche e unicità

Proprio la struttura portante del padiglione principale (padiglione A) rappresenta l'elemento di maggiore interesse: i progettisti decidono infatti di utilizzare una struttura reticolare completamente in legno, nonostante la disponibilità di tecnologie come cemento armato e l'acciaio, in voga in quel periodo.

Le dimensioni esterne (fig. 3) sono comprese tra gli 81,27 m della facciata est e gli 87,75 $\mathrm{m}$ della facciata ovest, con una larghezza pari a 25,40 m, toccando quota 19,74 m, per una superficie totale di $2.137 \mathrm{mq}$. II sistema portante principale è costituito da 15 telai a capriata con interasse compreso tra i 6,8 e i 7,3 m. I telai principali sono interconnessi con I I capriate secondarie con interasse variabile tra 1,6 e $3 \mathrm{~m}$. Le colonne, collegate ad un reticolo complesso, definiscono la struttura portante verticale con controventi a $\mathrm{N}$.

Le travi principali dividono la sala in tre navate, fissate sulla struttura e sulle colonne della facciata, che agiscono allo stesso tempo come supporto per le vetrate a griglia in legno su moduli di $40 \times 95 \mathrm{~cm}$.

La struttura non è mai visibile, poiché l'intero interno è stato progettato con boiserie in legno e casseri di finitura che la coprono: da qui la necessità di sviluppare alcuni percorsi divulgativi mirati alla valorizzazione della struttura stessa. 
Il padiglione B viene progettato a supporto per uffici e locali amministrativi, mentre il padiglione D, realizzato anch'esso in legno tranne per la parete centrale in pietra di Sljeme, ospita il bookshop.

Il padiglione $C$ è destinato a servizi ed è caratterizzato dal grande sporto del coperto e dal bilanciato rapporto forma/volume.

Fig. 3. Per la modellizzazione della struttura portant si è partiti dallo studio de progetto e dei documenti storicl, passando per il come teciche endiretto, che o termografiche.

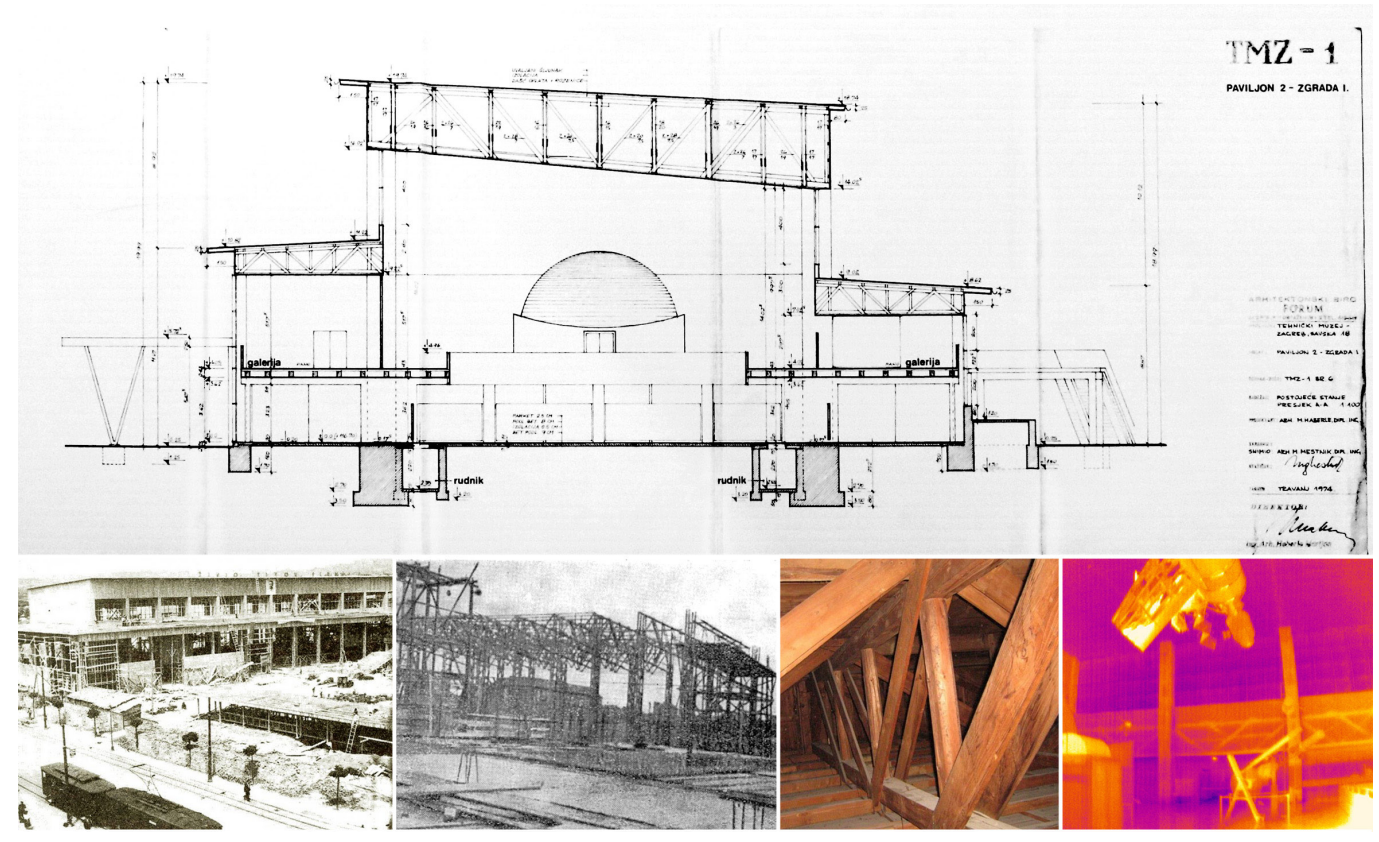

\section{Metodologia di rilievo e documentazione}

La complessità, sia in termini di valore storico-architettonico che funzionale-espositivo, ha richiesto una a metodologia di rilievo e documentazione che potesse, da un lato, integrare molteplici metodi e strumenti di acquisizione dati e che permettesse la loro aggregazione e il successivo riutilizzo. Per tale motivo si è optato per la realizzazione dei modelli BIM-based utilizzabili sia per la documentazione, gestione e verifica strutturale dell'edificio e utilizzabili per la realizzazione di applications di AR e VR. Diverse tecniche di acquisizione, integrate tra loro, sono state scelte in funzione degli scopi specifici seguendo le linee guida identificate nel protocollo di rilievo sviluppato all'interno del progetto INCEPTION [Di Giulio et al. 20 I7]. II rilievo

Per il rilievo del complesso architettonico si è utilizzata una metodologia ibrida, oggi consolidata, che si avvale di laser scanner terrestre e fotogrammetria aerea [Nex, Remondino 20 I 4], registrati tramite rete topografica. è stato utilizzato un FARO LS330 per il rilievo degli interni del padiglione $A$ e per l'esterno dellintero complesso, mentre si è utilizzato un drone, DJI Mavic 2 Pro, per il rilievo delle coperture e delle parti in elevazione nascoste da sporti o vegetazione [Fatta et al. 20 I7].

II rilievo laser scanner terreste (254 scansioni con 12 mm errore residuo) è stato registrato direttamente sulla rete topografica esistente (con capisaldi esterni ed interni), realizzata per il monitoraggio strutturale. II rilievo terreste, insieme ai capisaldi visibili dal drone (n. 5) sono stati utilizzati per migliorare la precisione dell'allineamento della foto-modellazione ( 1.500 immagini processate) e ridurre gli errori di deriva (fig. 3).

Per la costruzione del Virtual Tour del complesso, specifico per applicazioni off-site legate, si sono effettuate 123 foto sferiche $360^{\circ}$ ad alta risoluzione (10.000x5.000 px) acquisite in HDR tramite Ntech iStar. II Virtual Tour è stato poi realizzato con 36 immagini e successivamente popolate dalle informazioni contestuali. 
II rilievo dei manufatti, all'interno del museo, per la creazione e lo sviluppo di un'applicazione di AR è stato effettuato integrando i dati acquisiti da laser scanner (Faro Ls330) e fotogrammetria (Canon 5D Mark2 - $50 \mathrm{~mm} \mathrm{fl,4)} \mathrm{utilizzando} \mathrm{target} \mathrm{piani} \mathrm{per} \mathrm{la} \mathrm{registrazione.}$

II rilievo strutturale effettuato dall'Università di Zagabria [Rajčić at al. 20।3] inizia dallo studio del progetto e dei documenti storici verificato ed integrando il rilievo diretto tramite ispezioni e endoscopia o con tecniche indirette e non distruttive come termografia, ultrasuoni, resistografi, ecc. I dati raccolti sono poi stati impiegati per la definizione del modello tridimensionale e del suo arricchimento.

La modellazione $3 \mathrm{D}$ e i modelli BIM

La modellazione H-BIM architettonica del TMNT è stata realizzata con Autodesk Revit 20 I 8, con un LOD adeguato [3] all'inserimento di tutte le informazioni derivanti dai rilievi e dalle indagini realizzate strutturato con una organizzazione informativa, che possa essere utilizzabile dal personale del Museo, in sostituzione dei CAD 2D esistenti, per scopi gestionali e manutentivi, e possa essere aggiornato ed implementato per poter registrare anche i futuri interventi.

II modello BIM della struttura, realizzato anch'esso in Revit in collaborazione con I'Università di Zagabria [Rajčić et al. 2019], poneva la sfida di ricreare la complessa geometria della struttura, nascosta alla vista, partendo da documenti, rilievi e indagini effettuate.

La maggior parte degli elementi strutturali è stata modellata utilizzando i parametri geometrici disponibili, per semplificare la realizzazione, sia delle geometrie che delle proprietà dei singoli elementi e/o di gruppi, fondamentale per permettere modifiche nel corso del tempo, dovessero risultare disponibili nuove o più corrette informazioni provenienti da misurazioni in loco, come verifiche e analisi puntuali.

Fig. 4. II rilievo del complesso del Museo è stato effettuato con una metodologia ibrida, utilizzando il laser scanne terrestre integrato alla fotogrammetria aerea, registrati tramite l'utilizzo di capisaldi topografici.
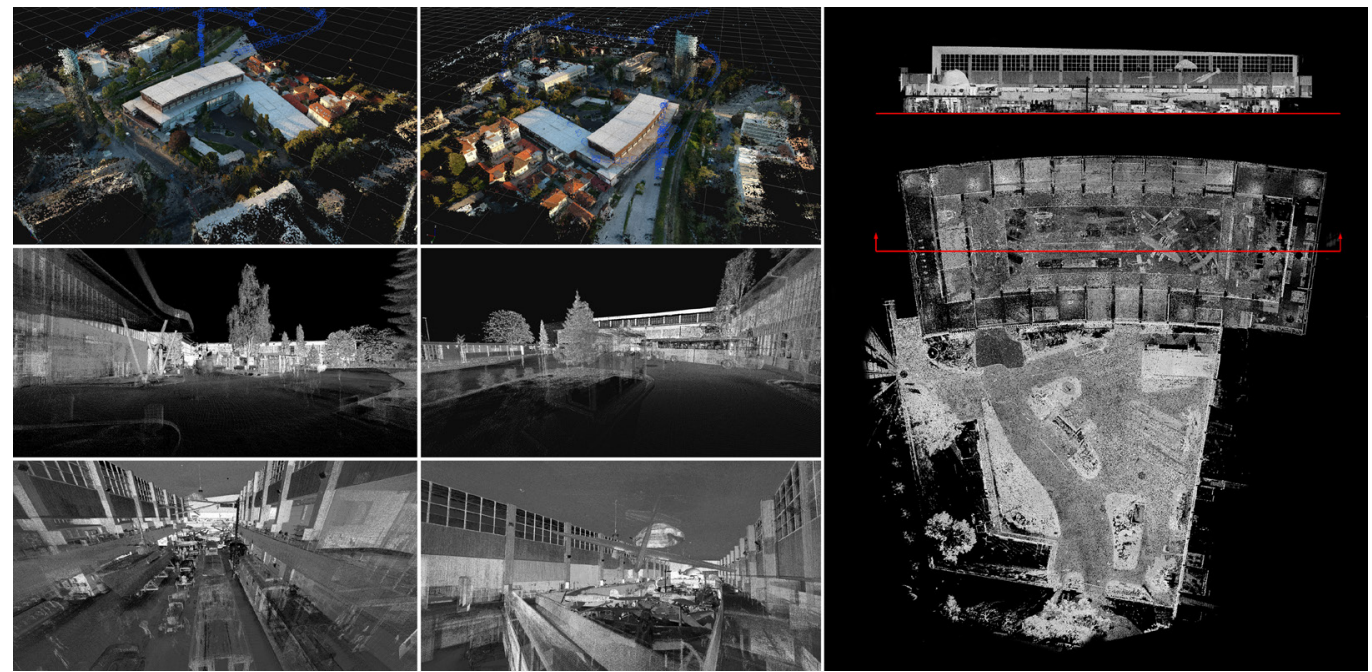

L'arricchimento semantico del modello BIM e la popolazione con documentazioni allegata I modelli BIM sono stati realizzati (architettonico e strutturale) secondo lo standard IFC $2 \times 3$, in modo che i singoli elementi vengano correttamente classificati una volta caricati sulla piattaforma INCEPTION [Maietti et. al. 2020), dove convertiti in TTL [Bonsma et. al. 20 I 8], possono essere ulteriormente arricchiti semanticamente o con allegati di diverso tipo (PDF, relazioni strutturali, termografie, immagini, modelli 3D di dettaglio, ecc.), connessi ai singoli elementi del modello (fig. 5).

Allo stesso modo, le informazioni già contenute nel modello IFC vengono trasferite automaticamente alla piattaforma INCEPTION, come, ad esempio quelle sul materiale, le proprietà tecniche dell'elemento, la funzione (elemento portante, chiusura esterna, partizione interna etc.) o la fase di realizzazione/manutenzione [4]. 
Fig. 5. La modellazione H-BIM architettonica del Museo e della sua struttura portante è stata realizzata con il software Autodesk Revit 2018 sfruttando un workflow condiviso. II modello sviluppato con un LOD adeguato alle informazioni disponibili è strutturato con una organizzazione informativa che possa inormativa che possa permettere di essere un continuo ageo per un continuo aggiornamento ed implementato nel tempo.

I modelli sono stati poi caricati all'interno della piattaforma INCEPTION per essere arricchiti semanticamente e per poter connettere ai singoli elementi del modello allegati di diverso tipo. Nell'immagine a destra uno screeenshoot dell piattaforma INCEPTION dove si può impostare una modalità di visualizza una modalità di visualizzazione blended tra mode
La piattaforma INCEPTION può filtrare le diverse tipologie di dati in funzione della tipologia utenti tramite un efficace sistema di fruizione. L'ingegnere strutturale può, ad esempio, facilmente scegliere tra le informazioni importanti per la valutazione delle condizioni della struttura, scegliendo i dati relativi alle prestazioni strutturali (indagini, restauri o interventi precedenti), seguiti dalla geometria (disegni 2D e modelli 3D) e dalla documentazione fotografica degli elementi, per verificarne le effettive condizioni. Con l'integrazione di tutti i dati nel modello BIM, il tecnico può definire gli interventi futuri e prevedere in maniera più consapevole sistemi appropriati di retrofitting [Cadelano et al. 2019].
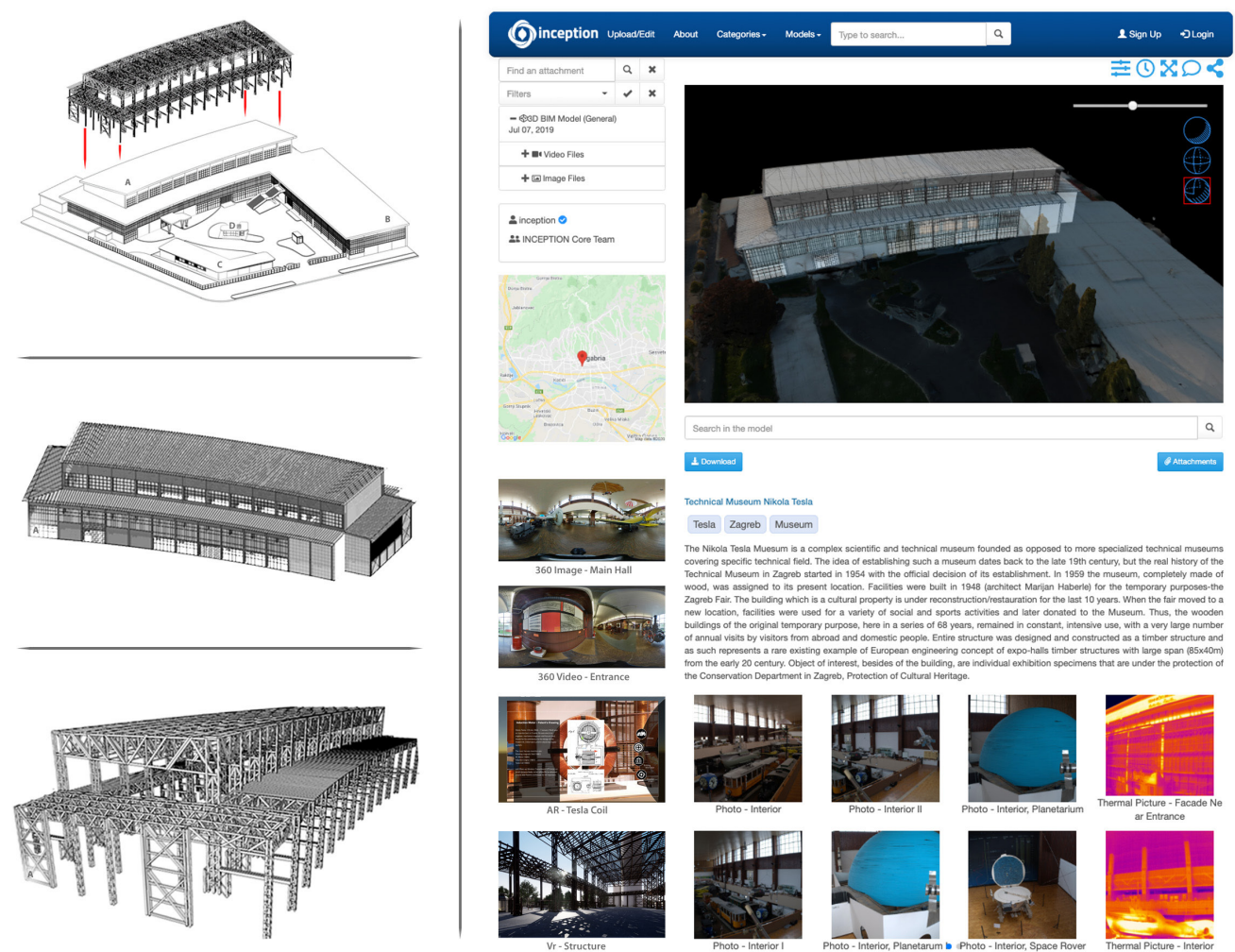

\section{Risultati e applicazioni di AR/VR per la fruizione dei contenuti documentati}

A partire del rilievo e dai modello BIM, sono stati elaborati modelli tridimensionali finalizzati alla creazione di applicazioni di realtà virtuale (VR) o aumentata (AR) [Parrinello et al. 20 I6]. Nella maggior parte dei casi sono stati ri-processati, ottimizzati e ridefiniti tramite superfici semplici o NURBS, impiegando Rhino o Sketchup [Ausonio et al. 20 I 8]. Questo ha permesso di apportare le semplificazioni, dove necessario, per risolvere il problema del peso informatico del modello o della scena, uno dei maggiori limiti nell'utilizzo di queste tecnologie. Nella configurazione dei modelli è stato di fondamentale importanza la definizione a priori dello storytelling che la comunicazione in AR/VR avrebbe sviluppato.

Si è ridefinita la struttura topologica dei modelli, in funzione dei fattori percettivi, lavorando sulle texture per ottenere un'efficacie riduzione geometrica. L'utilizzo del texture baking ha permesso una semplificazione della struttura volumetrica, integrando l'effetto della luce nella texture stessa. Tramite l'utilizzo di Twinmotion, si è realizzata un'esperienza di navigazione VR off-site del complesso, rendendo così possibile inoltre la fruizione e la valorizzazione della struttura portante nascosta (fig. 6).

Lo sviluppo dimostrativo di un'app in AR per smartphone valorizza on-site la struttura, sovrapponendola dinamicamente in tempo reale, all'interno della sala grande. La stessa ap- 
Fig. 6. Tramite l'utilizzo della piattaforma Twinmotion (Unreal Engine) si è realizzata un'esperienza di navigazione di realtà virtuale off-site sul complesso architettonico del museo in relazione alla sua struttura portante.

L'immagine mostra anch i diversi livelli di approfondimento del modello architettonico necessari alla realizzazione immersiva della scena VR.

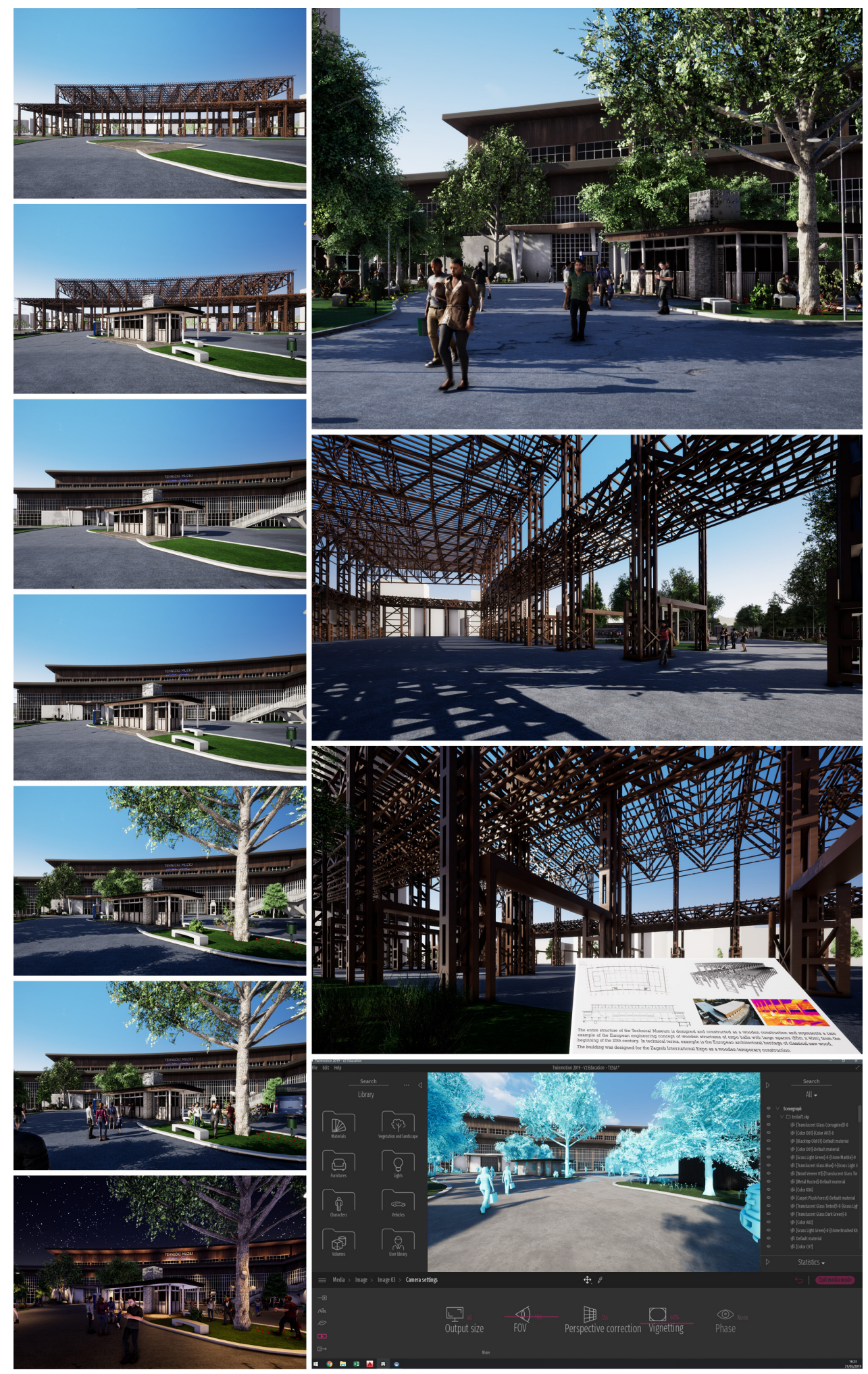


Fig. 7. Per l'applicazione di realtà aumentata AR si sono scelti con il curatore alcuni oggetti da valorizzare con questa tecnologia all'interno del museo,

tra cui una delle bobine

di Tesla ed un prototipo

di auto elettrica realizzato

di una azienda croata.

Nell'immagine inoltre è

presente la visualizzazio-

ne della funzione dell'app

che valorizza la struttura

chalo viza

sovrapponendola, dina-

reale, all'interno della

sala grande. Lo sviluppo

è stato effettuato in

ambiente Unity.
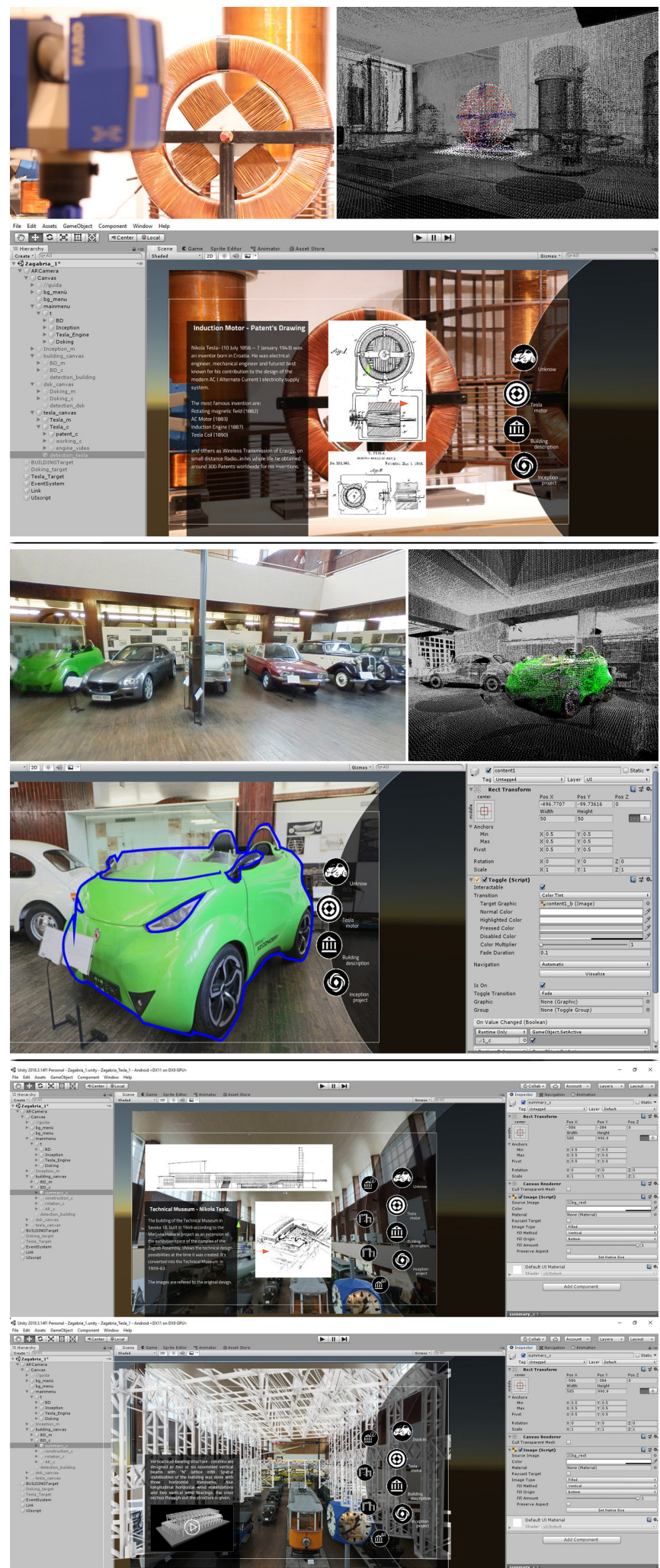
plicazione integra la fruizione aumentata di tre manufatti esposti, identificati con il curatore del museo: una bobina di Tesla, un prototipo di auto elettrica dell'azienda croata Dock-In e un'autopompa a vapore di fine '800. La tecnologia di riconoscimento utilizzata è basta sugli algoritmi di Vuforia per lo sviluppo in Unity. Gli oggetti della collezione museale diventano quindi punti di accesso per la fruizione di contenuti aggregati, direttamente e dinamicamente prelevati dalla piattaforma INCEPTION (fig. 7).

La stessa logica di recupero on-the-fly dei contenuti presenti sulla piattaforma è stata adottata anche per il Virtual Tour del museo e della sua collezione. Un prodotto raster-based realizzato a partire dalle foto $360^{\circ}$, caricato sulla piattaforma e spazialmente connesso al modello BIM. II Virtual Tour è stato pensato principalmente per l'utilizzo via browser web, headset VR all-in-one o dispositivi mobiles (fig. 8).

Fig. 8. II Virtual Tour del museo è stato realizzato a partire da 36 delle 12 foto sferiche $360^{\circ}$, acquisite durante la campagna di rilievo, ed è stato pensato principalmente per l'utilizzo via browser web, headset VR all-in-one o dispositivi mobile.
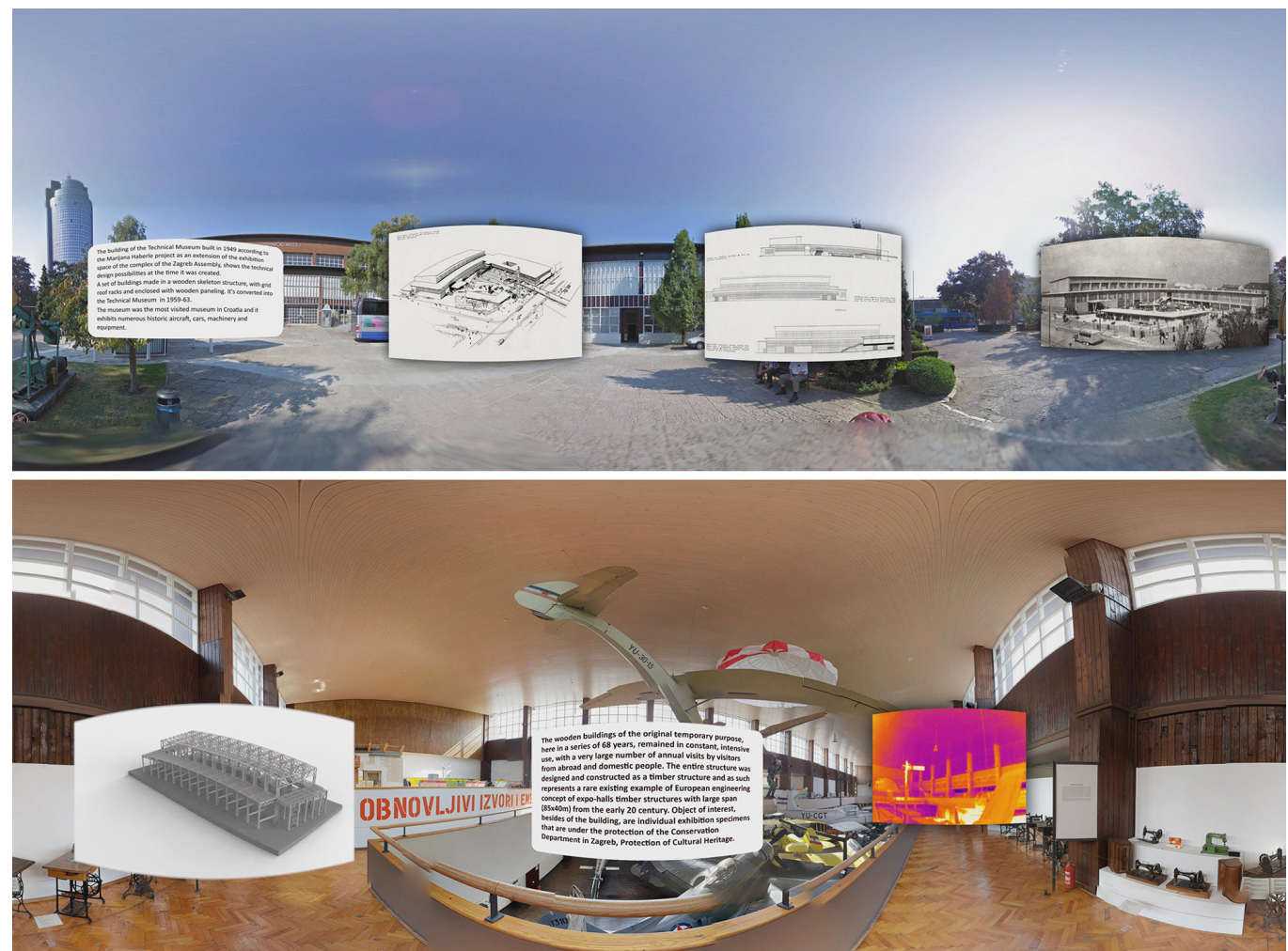

\section{Conclusioni e sviluppi futuri}

II complesso, costruito nel 1949 come struttura temporanea, viene realizzato in un'epoca in cui il legno lamellare era quasi sconosciuto, rendendo questo edificio un progetto di assoluto interesse, dove ambizione e audacia del progettista, impressiona ancora oggi. L'imponente struttura lignea è un prezioso esempio di architettura croata del dopoguerra e, nel 2005, è stata inclusa tra i beni culturali protetti.

Nonostante questo, l'architettura del museo Tesla risultava ancora scarsamente indagata prima del presente progetto. Le moderne tecniche di rilievo e modellazione BIM messe in atto hanno permesso non solo di capire, preservare e gestire il manufatto ma sono diventate la base per la comunicazione di tale valore. I nuovi media come il web e gli strumenti di realtà virtuale e realtà aumentata divengono pertanto strumento lessicale di dialogo e racconto per le nuove generazioni, aprendo a successivi riutilizzi in una logica comunicazione trasversale e trasferimento culturale intergenerazionale. 


\section{Note}

[I] Sperimentazione effettuata all'interno del progetto europeo "INCEPTION - Inclusive Cultural Heritage in Europe through 3D semantic modelling", conclusosi a Maggio 2019 e finanziato della Commissione Europea nell'ambito del Programma Horizon 2020, Research and Innovation Action sotto il Grant Agreement No. 665220.

[2] Sito web del Museo della Tecnica in Nikola Tesla: <tmnt.hr/hr-hr>.

[3] Riferibile ad un LOD F/G previsto dalla normativa italiana UNI I I 337-4:20 I 7 per le opere di interesse storico-architettonico.

[4] Uno specifico set di proprietà, permette di estendere lo standard IFC $2 \times 3$ e includere nomenclature delle componenti secondo il vocabolario Getty, attraverso indirizzamento specifico della piattaforma INCEPTION tramite link.

\section{Riferimenti bibliografici}

Ausonio Elena, Battini Carlo, Fagandini Roberta, Federici Bianca et al. (2018). Potenzialità dei software Free e/o Open Source per la modellazione, gestione e fruizione di entità 3D. In Geomatics Workbooks, n. 14 - FOSS4G-it.

Bonsma Peter, Bonsma Iveta, Ziri Anna Elisabetta, ladanza Ernesto et al. (20I8). Handling huge and complex 3D geometries with Semantic Web technology. In IOP Conference Series: Materials Science and Engineering, vol. 364, No. I, pp. I2-4I.

Brusaporci Stefano, Ruggieri Gianfranco, Sicuranza Filippo, Maiezza Pamela (20 I 7). Augmented Reality for Historical Storytelling The INCIPICT Project for the Reconstruction of Tangible and Intangible Image of L'Aquila Historical Centre. In Proceedings, I, 1083

Cadelano Gianluca, Cicolin Francesco, Emmi Giuseppe, Mezzasalma Giulia et. Al. (2019). Improving the Energy Efficiency, Limiting Costs and Reducing CO2 Emissions of a Museum Using Geothermal Energy and Energy Management Policies. In Energies 2019, 12,3192.

Di Giulio Roberto, Maietti Federica., Piaia Emanuele, Medici Marco et al. (20 I7). Integrated data capturing requirements for 3D semantic modelling of Cultural Heritage: the INCEPTION protocol. In Int. Arch. Photogramm. Remote Sens. Spatial Inf. Sci., XLII-2/W3, 25I-257.

Fatta Francesca, Bassetta Manuela, Manti Andrea (2017). Survey Methodologies, Research and Technological Innovation for a Case of Medieval Archaeology:Torre Melissa in the province of Crotone. In DisegnareCon 10(19), 6-I.

Maietti Federica, Di Giulio Roberto, Medici Marco, Ferrari Federico et al. (2020). Documentation, Processing, and Representation of Architectural Heritage Through 3D Semantic Modelling: The INCEPTION Project. In Bolognesi Cecilia, Santagati Cettina (eds.). Impact of Industry 4.0 on Architecture and Cultural Heritage. Hershey, PA: IGI Global, pp. 202-238.

Nex Francesco, Remondino Fabio (20 I4). UAV for 3D mapping applications: a review. In Applied geomatics, 6( I), I - I 5.

Parrinello Sandro, Picchio Francesca, Bercigli Monica (20 I 6). La 'migrazione' della realtà in scenari virtuali: Banche dati e sistemi di documentazione per la musealizzazione di ambienti complessi. Musei virtuali dell'architettura e della città. In Disegnarecon, $9(17), 14-1$

Rajčić Vlatka, Čizmar Dean, Stepinac Mislav (2013). Reconstruction of the Technical Museum in Zagreb. In Advanced Materials Research 778, 919-926.

Rajčić Vlatka, Stepinac Mislav, Barbalić Jure (2019). In Situ Advanced Diagnostics and Inspection by Non-destructive Techniques and UAV as Input to Numerical Model and Structural Analysis - Case Study. In Moropoulou Antonia, Korres Manolis, Georgopoulos Andreas, Spyrakos Constantine, Mouzakis Charalambos (eds.). Transdisciplinary Multispectral Modeling and Cooperation for the Preservation of Cultural Heritage. TMM_CH 2018. Communications in Computer and Information Science, vol 962. Cham: Springer.

Vranić Dubravka (2020). The Zagreb Fair as a Generator of New Zagreb's Planning. In Journal of Planning History.

\section{Autori}

Marco Medici, Università di Ferrara, marco.medici@unife.it

Federico Ferrari, Università di Ferrara, federico.ferrari@unife.it

Per citare questo capitolo: Medici Marco, Ferrari Federico (2020). Rilievo e documentazione del museo Tesla a Zagabria per la valorizzazione mediante applicazioni di AR eVR/ Survey and documentation of the Tesla Museum in Zagreb for the valorisation through AR andVR applications. In Arena A., Arena M., Brandolino R.G., Colistra D., Ginex G., Mediati D., Nucifora S., Raffa P. (a cura di). Connettere. Un disegno per annodare e tessere Atti del $42^{\circ}$ Convegno Internazionale dei Docenti delle Discipline della Rappresentazione/Connecting. Drawing for weaving relationships. Proceedings of the 42th International Conference of Representation Disciplines Teachers. Milano: FrancoAngeli, pp. 24I 4-2433. 


\title{
Survey and Documentation of the Tesla Museum in Zagreb for the Valorization through AR and VR Applications
}

\author{
Marco Medici \\ Federico Ferrari
}

\section{Abstract}

The paper presents the experience of survey, documentation and valorization of the Tesla Museum in Zagreb. For the survey of the architectural complex a hybrid methodology has been used, today consolidated, which makes use of laser scanner integrated with photogrammetry techniques, both aerial and terrestrial for the detail of artefacts. The data collected served as the basis for the realization of architectural and structural BIM-based models, then enriched with the technologies offered by the INCEPTION platform in order to aggregate the further documentation collected towards the creation of $\mathrm{H}$-BIM models. The latter have then allowed their exploitation, through appropriate optimizations, in immersive environments of virtual and augmented reality for the enjoyment of the value of the architectural work and artifacts contained herein.

Keywords

survey, documentation, virtuality, virtual reality, augmented reality.
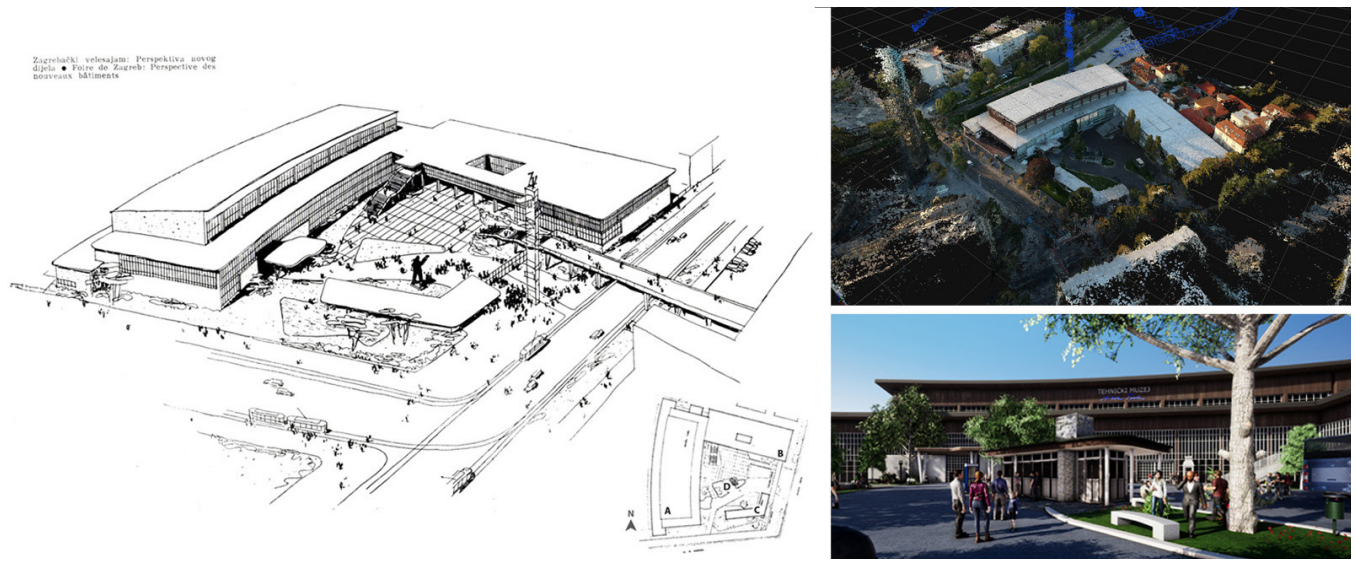


\section{Classification and scope of investigation}

The survey, documentation and valorization of the spaces and exhibition design of the Tesla Museum in Zagreb (TMNT) is part of the case studies of the INCEPTION project [I], with the aim of enhancing and developing communication tools to be used within the museum, in order to strengthen the understanding of the museum path and the role of the museum in the economic, urban and historical-political development of the former Yugoslavia.

To this end, the INCEPTION platform has been used as an aggregator element of all specific information, through 3D BIM-based models, used for verification and structural analysis of the building (FEM model), as an aid to decision making strategies in terms of maintenance and for web-mobile applications of virtual reality (VR) or augmented reality (AR) for tourism-information, dissemination and cultural marketing.

The history of the complex

The complex in which the Tesla Museum is located today (fig. I), originally known as the Zagreb Assembly on Savska Street, was built on the basis of a project by Marijan Haberle and Hinko Bauer, already almost entirely completed in 1939.

Since 1909, with a series of pavilions, built as a venue for trade fair events, Zagreb has been enriched with interesting architectural structures, among which the French pavilion stands out.

After the First World War, it is evident that the area of the Assembly is used as an instrument of cultural diplomacy, with the aim of proving the capacity and economic strength of neo-Yugoslavia.

In 1946 the Assembly area was renamed Zagreb Fair (Vranić 2020) and the decision was taken to expand the 13,400 square meters of exhibition space, which proved to be insufficient.

In 1949, in 8 months, the architect Marijan Haberle built new pavilions for 8,000 square meters at 39 Savska Street in front of the original nucleus, now the Student Center (fig. 2). The main building, which replaces a tram depot, has an innovative wooden supporting structure.

Fig. I. Aerial view of the complex of the area of the former Zagreb Fairground realized on the basis of the project by Marijan Haberle and Hinko Bauer. The French pavilion, the student centre and the Tesla Museum are highlighted. The picture below shows the "square" at the entrance to the Museum with the four pavilions.

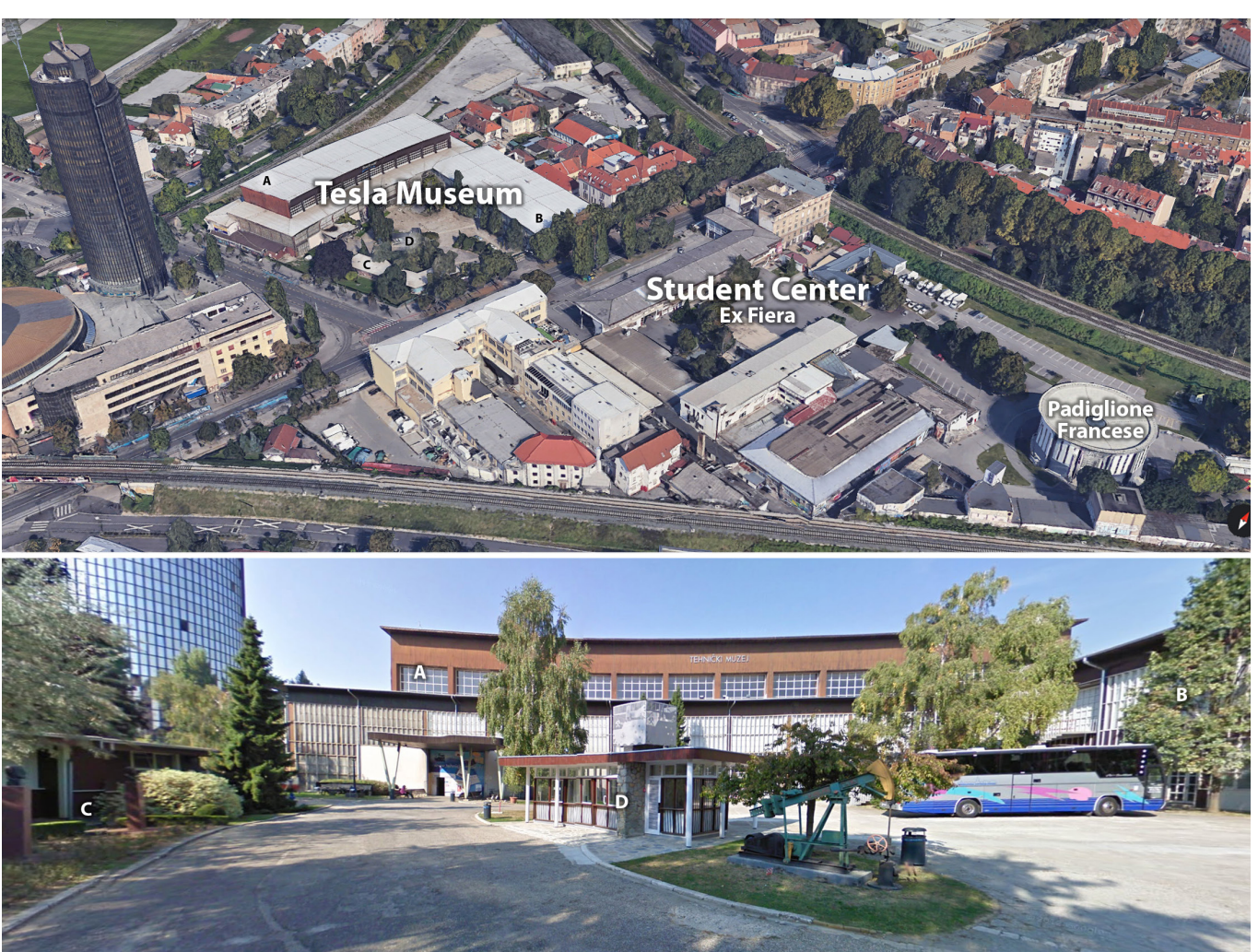


Fig. 2. Drawings and historical photos of the Museum, including the one of the opening day In the perspective, it is worth noting the prefabricated steel bridge for the crossing of Savska street (as a connection to the former Fair) and the vertical column of 30 meters in steel tubes, both never built The rhythm of the façades is hightighted by fçades is high the designer.
The larger structure (pavilions A and B), with a partially curved L-shaped layout, is positioned in depth, while another pavilion closes the intersection (pavilion C) creating a square as access and placing another small pavilion (D) inside.

A prefabricated bridge to cross Savska street (connection to the old part) and a vertical column of 30 meters, with urban relevance and an advertising-commercial declination, should have completed the project but were not realized.

After 1950 these last pavilions were transformed into the Museum of Science and Technology when the Fair was fully re-functionalized for commercial purposes, following the role of the Soviet Union as a new and main political-economic partner. More precisely, from 1954 to 1959 the Fair was moved to a new location, while the museum was officially opened in 1963 and from 2015 it was named after Nikola Tesla [2].
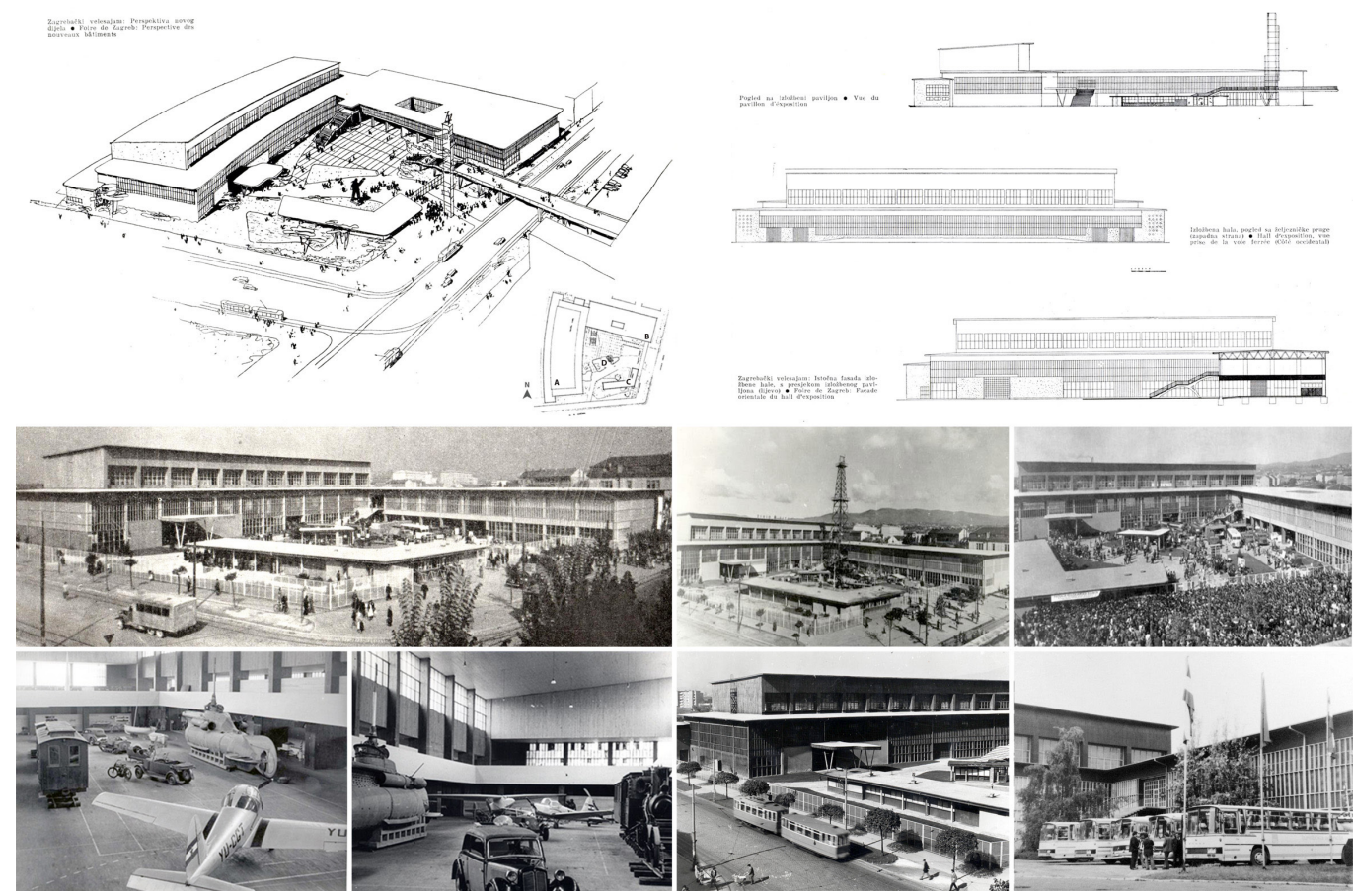

The main structure of the museum: characteristics and uniqueness

The load-bearing structure of the main pavilion (Pavilion A) represents the most interesting element: the designers decided to use a reticular structure completely made of wood, despite the availability of technologies such as reinforced concrete and steel, in vogue at the time.

The external dimensions (fig. 3) are between $81.27 \mathrm{~m}$ of the east facade and $87.75 \mathrm{~m}$ of the west facade, with a width of $25.40 \mathrm{~m}$, reaching a height of $19.74 \mathrm{~m}$, for a total area of 2, I 37 m2.The main load-bearing system consists of 15 truss frames with a span between 6.8 and $7.3 \mathrm{~m}$. The main frames are interconnected with I I secondary trusses with a span between 1.6 and $3 \mathrm{~m}$. The columns, connected to a complex grid, define the vertical supporting structure with $\mathrm{N}$ shaped bracing.

The main beams divide the hall into three naves, fixed on the structure and the columns of the facade, which act at the same time as a support for the wooden grid windows on $40 x$ $95 \mathrm{~cm}$ modules.

The structure is never visible, since the entire interior has been designed with wood paneling and finishing formwork that cover it: hence the need to develop a number of informative paths aimed at enhancing the structure itself. 
Fig. 3. For the modeling of the load-bearing structure, we started from the study of the project and historical documents, passing through direct and indirec survey, such as endoscopic or thermographic techniques.
Pavilion B is designed to support offices and administrative premises, while Pavilion D, also made of wood except for the central part with Sljeme stone walls, hosts the bookshop. Pavilion $C$ is intended for services and is characterized by the large span of the covered area and the balanced shape/volume ratio.

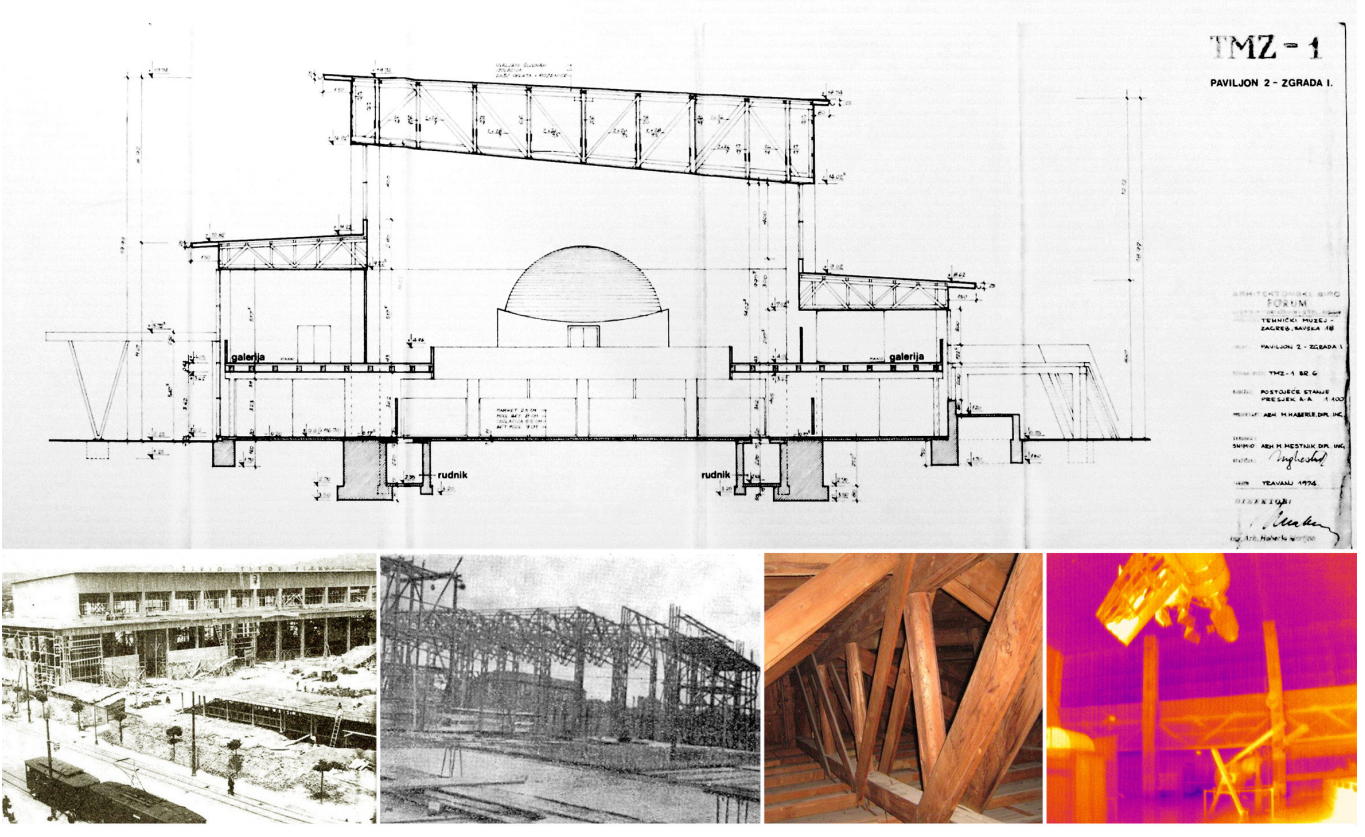

\section{Survey methodology and documentation}

The complexity, both in terms of historical-architectural and functional-expository value, required a survey and documentation methodology that could, on the one hand, integrate multiple data acquisition methods and tools and allow their aggregation and subsequent reuse. For this reason, we opted for the realization of BIM-based models that could be used both for the documentation, management and structural verification of the building and for the realization of $A R$ and VR applications. Several acquisition techniques, integrated with each other, have been chosen according to specific purposes following the guidelines identified in the survey protocol developed within the INCEPTION project [Di Giulio et al. 2017$]$.

The survey

For the survey of the architectural complex a hybrid methodology has been used, now consolidated, which makes use of terrestrial laser scanner and aerial photogrammetry [Nex, Remondino 2014], recorded through topographic network. A FARO LS330 was used to survey the interiors of Pavilion $A$ and the exterior of the entire complex, while a drone, DJI Mavic 2 Pro, was used for the survey of the roofs and the parts in elevation hidden by spokes or vegetation [Fatta et al. 2017].

The terrestrial laser scanner survey (254 scans with $12 \mathrm{~mm}$ residual error) has been recorded directly on the existing topographic network (with external and internal control points), realized for structural monitoring. The land survey, together with the control points visible from the drone (n. 5) were used to improve the accuracy of the photo-modeling alignment ( I,500 processed images) and reduce drift errors (fig. 4).

For the construction of the Virtual Tour of the complex, specific for off-site related applications, 123 high resolution $360^{\circ}$ spherical photos (10,000×5,000px) acquired in HDR through Ntech iStar were taken.The Virtual Tour was then realized with 36 images and then populated with contextual information. 
The survey of the artefacts, inside the museum, for the creation and development of an AR application was carried out by integrating the data acquired by laser scanner (Faro LS330) and photogrammetry (Canon 5D Mark2 - 50 mm fl.4) using flat targets for recording.

The structural survey carried out by the University of Zagreb [Rajčić at al. 20 I 3] starts from the study of the verified project and historical documents and integrates the direct survey by means of inspections and endoscopy or by indirect and non-destructive techniques such as thermography, ultrasound, resistographs, etc. The data collected were then used for the definition of the three-dimensional model and its enrichment.

3D modeling and BIM models

The architectural H-BIM modeling of the TMNT has been realized with Autodesk Revit 2018 , with a LOD suitable [3] for the insertion of all the information deriving from the surveys and investigations carried out, structured with an information organization that can be used by the Museum staff, in place of the existing 2D CAD, for management and maintenance purposes, and can be updated and implemented to record future interventions. The BIM model of the structure, also produced in Revit in collaboration with the University of Zagreb [Rajčić at al. 2019], posed the challenge of recreating the complex geometry of the structure, hidden from view, from documents, surveys and investigations carried out. Most of the structural elements have been modelled using the available geometrical parameters, in order to simplify the realization of both the geometries and the properties of the individual elements and/or groups, which is fundamental to allow changes over time, should new or more correct information from on-site measurements be available, such as verifications and punctual analysis.

Fig. 4. The survey of the Museum complex was carried out using a hybrid methodology, using the terrestrial laser scanner integrated with aerial photogrammetry recorded through the use of toporic strongholds.
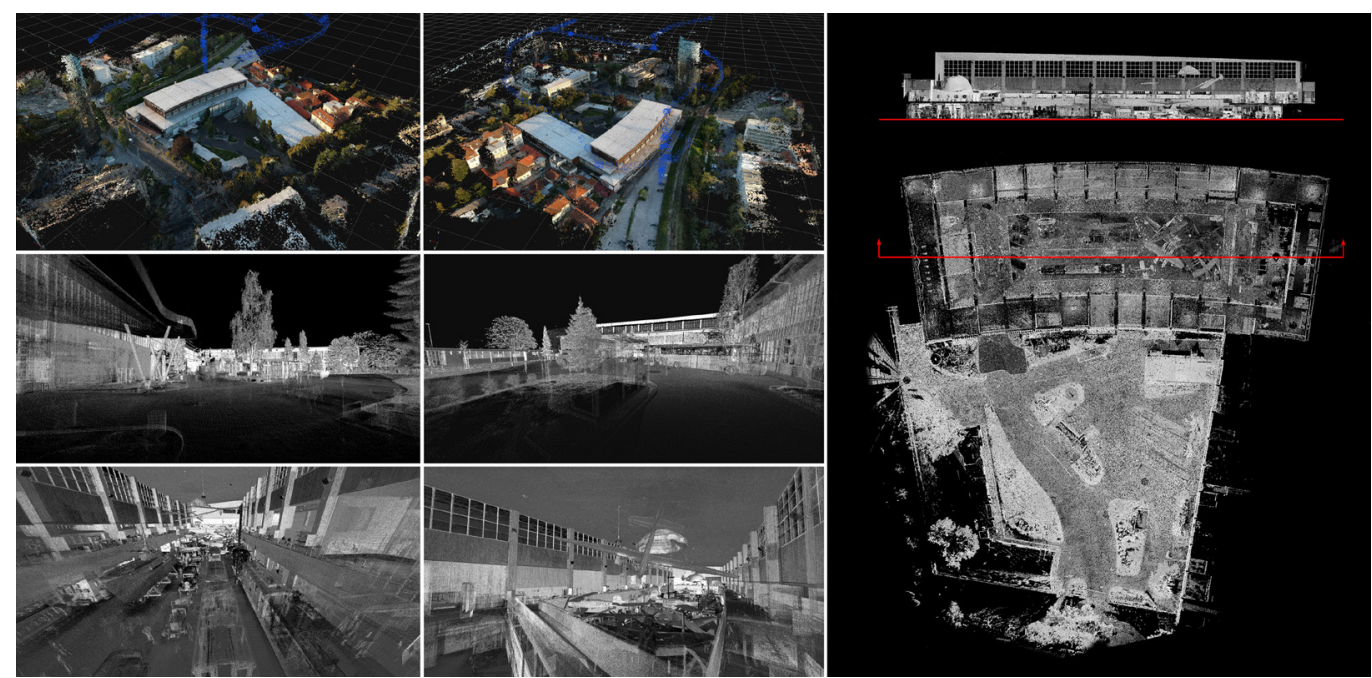

The semantic enrichment of the BIM model and the population with attached documentation BIM models have been realized (architectural and structural) according to the IFC $2 \times 3$ standard, so that the single elements are correctly classified once loaded on the INCEPTION platform [Maietti et al. 2020], where converted into TTL [Bonsma et. al. 20 I 8], they can be further enriched semantically or with attachments of different types (PDF, structural reports, thermographies, images, 3D detail models, etc.), linked to the individual elements of the model (fig. 5).

In the same way, the information already contained in the IFC model is automatically transferred to the INCEPTION platform, such as the material, the technical properties of the element, the function (load-bearing element, external closure, internal partition etc.) or the construction/maintenance phase [4]. 
Fig. 5. Architectural H-BIM modeling of the Museum and its supporting

structure was performed with Autodesk Revit 2018 software using a shared workflow. The model developed with a LOD adapted to the available information avallable information is structured with an that that can be used by the Museum for continuous updating and implementation over time. The models were then loaded inside the INCEP TION platform to be semantically enriched and to be able to connect attachments of different types to the individual elements of the model. In the image on the right a screenshot of the right a screenshot of the INCEPTION platform where you can set a blended display mode between BIM m
The INCEPTION platform can filter the different types of data according to the type of users through an effective system of fruition. The structural engineer can, for example, easily choose among the important information for the evaluation of the conditions of the structure, choosing the data related to the structural performance (surveys, restorations or previous interventions), followed by the geometry (2D drawings and 3D models) and the photographic documentation of the elements, to verify the actual conditions. With the integration of all data in the BIM model, the technician can define future interventions and foresee more consciously appropriate retrofitting systems [Cadelano et al. 2019].
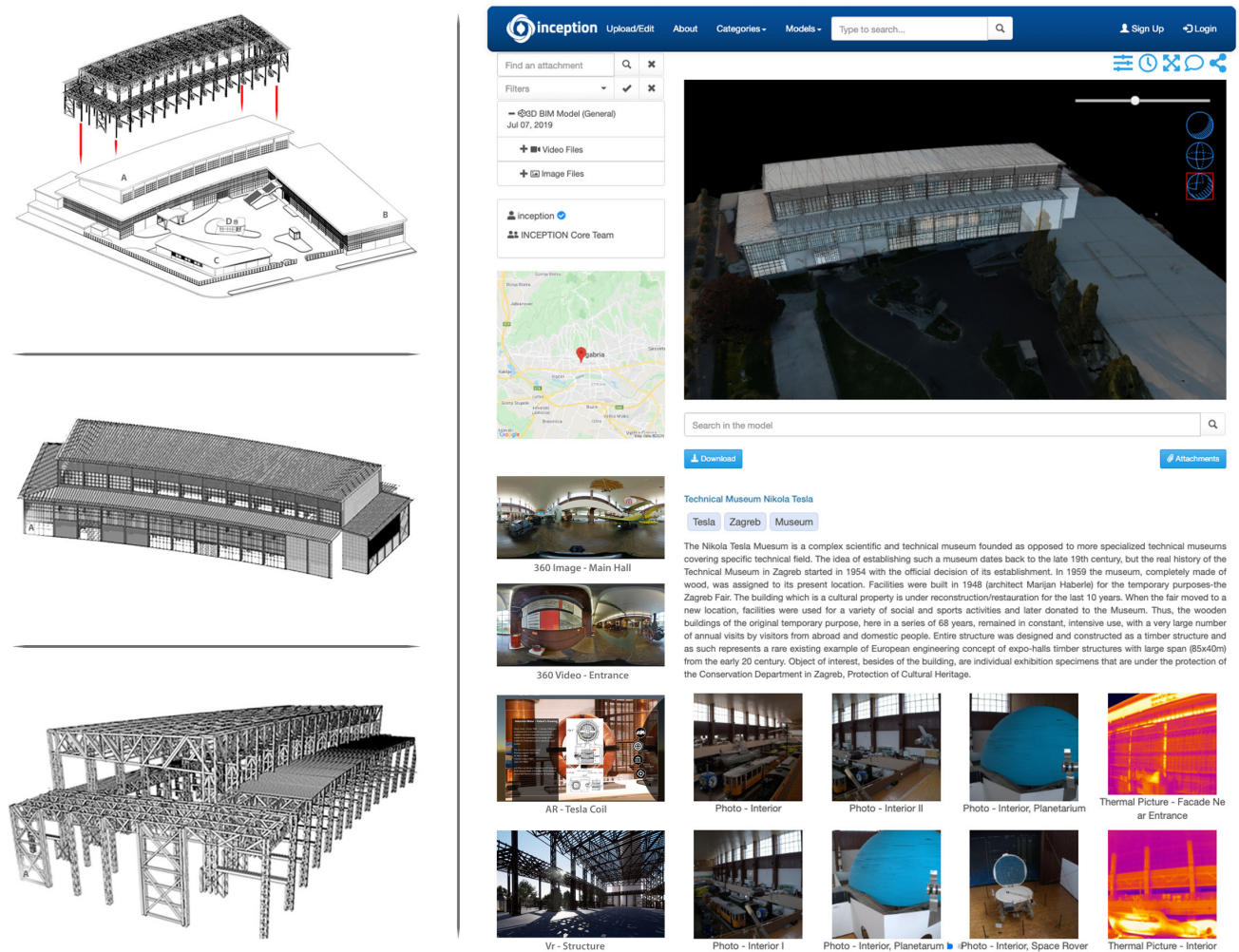

\section{Results and applications of AR/VR for the fruition of the documented contents}

Starting from the survey and the BIM model, three-dimensional models have been developed for the creation of virtual (VR) or augmented (AR) reality applications [Parrinello et al. $2016]$. In most cases they were re-processed, optimized and redefined using simple surfaces or NURBS, using Rhino or Sketchup [Ausonio et al. 20 18]. This has allowed simplifications, where necessary, to solve the problem of the computer weight of the model or scene, one of the major limitations in the use of these technologies.

In the configuration of the models it was of fundamental importance the a priori definition of the storytelling that the AR/VR communication would develop.

The topological structure of the models has been redefined, according to perceptual factors, working on the textures to obtain an effective geometric reduction. The use of the texture baking, has allowed a simplification of the volumetric structure, integrating the effect of light into the texture itself.Through the use of Twinmotion, a VR off-site navigation experience of the complex has been achieved, making it possible to use and enhance the hidden load-bearing structure (fig. 6).

The demonstration development of an AR app for smartphones enhances the structure on-site, dynamically overlapping it in real time, inside the large room. The same app inte- 
Fig. 6. Through the use of the Twinmotion
(Unreal Engine) platform, an off-site virtual reality navigation experience has been realized on the architectural complex of the museum in relation to its supporting structuthe different levels of deepening of the architectural model necessary for the immersive realization of the VR scene.

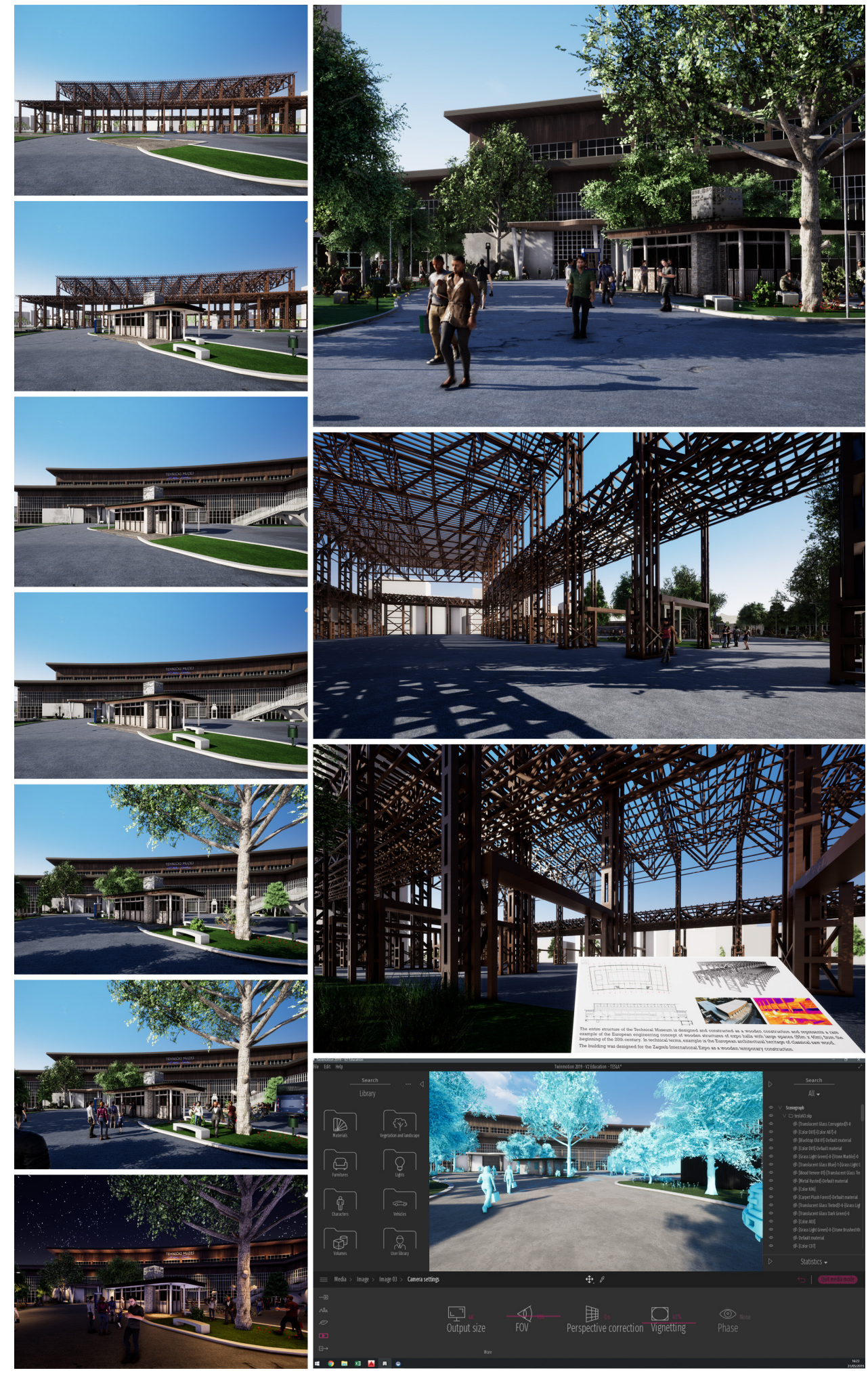


Fig. 7. For the application of AR augmented reality, we choose with the curator some objects to be enhanced with this technology inside the museum including one ofTesla's coils and an ectric car prototype electric car prototype pany. In the image there is also the visualization of the function of the app that enhances the structure by superimposing it, dynamically and in real time, inside the big room. The development was carried out in Unity environment.
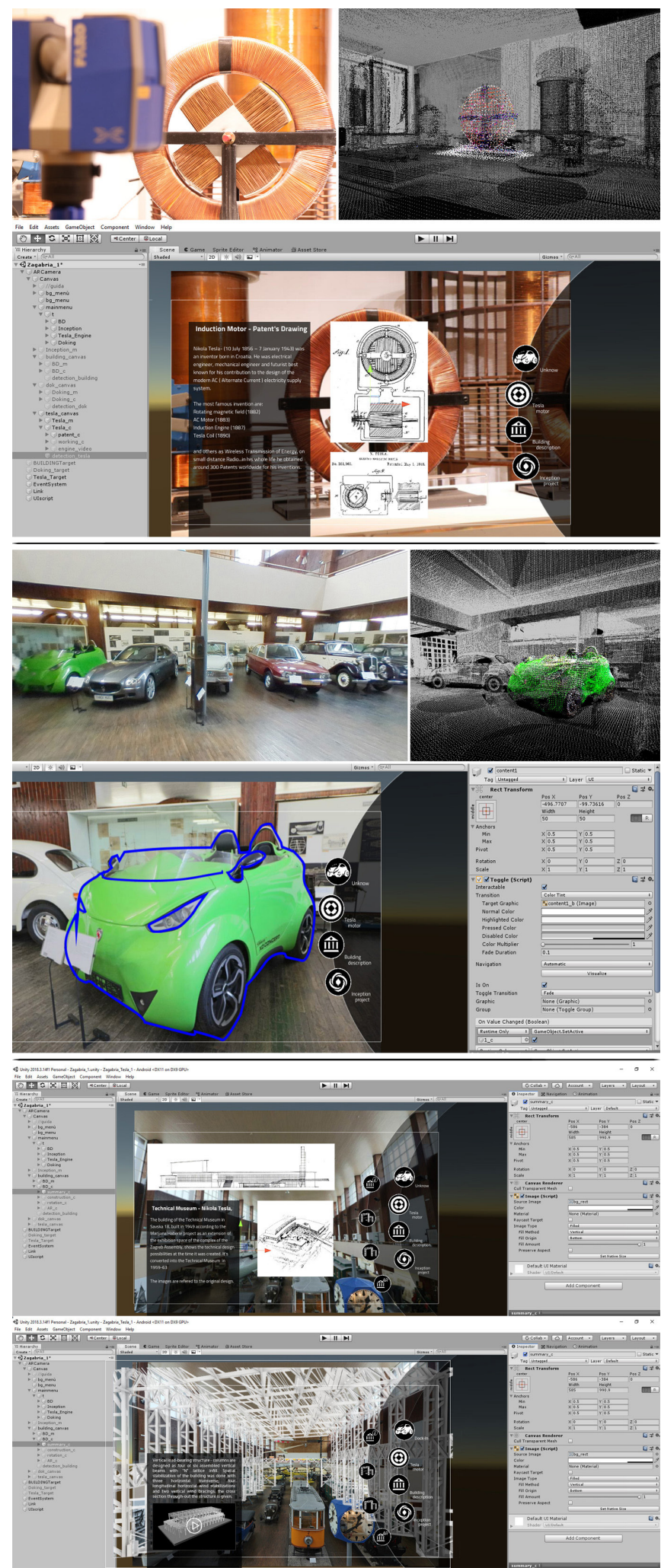
grates the increased use of three artifacts on display, identified with the museum's curator: a Tesla coil, a prototype electric car from the Croatian company Dock-In and a late 19th century steam engine. The recognition technology used is based on Vuforia's algorithms for development in Unity. The objects in the museum collection thus become access points for the enjoyment of aggregated content, directly and dynamically taken from the INCEPTION platform (fig. 7).

The same logic of on-the-fly retrieving of the contents on the platform has been adopted for the Virtual Tour of the museum and its collection. A raster-based product made from $360^{\circ}$ photos, loaded on the platform and spatially connected to the BIM model. The Virtual Tour was designed primarily for use via web browser, all-in-one VR headset or mobile devices (fig. 8).

Fig. 8. The Virtual Tour of the museum has been realized starting from 36 of the $123360^{\circ}$ spherical photos, acquired during the survey campaign, and has been designed mainly for use via web browser. al-in-one VR headset or allin-
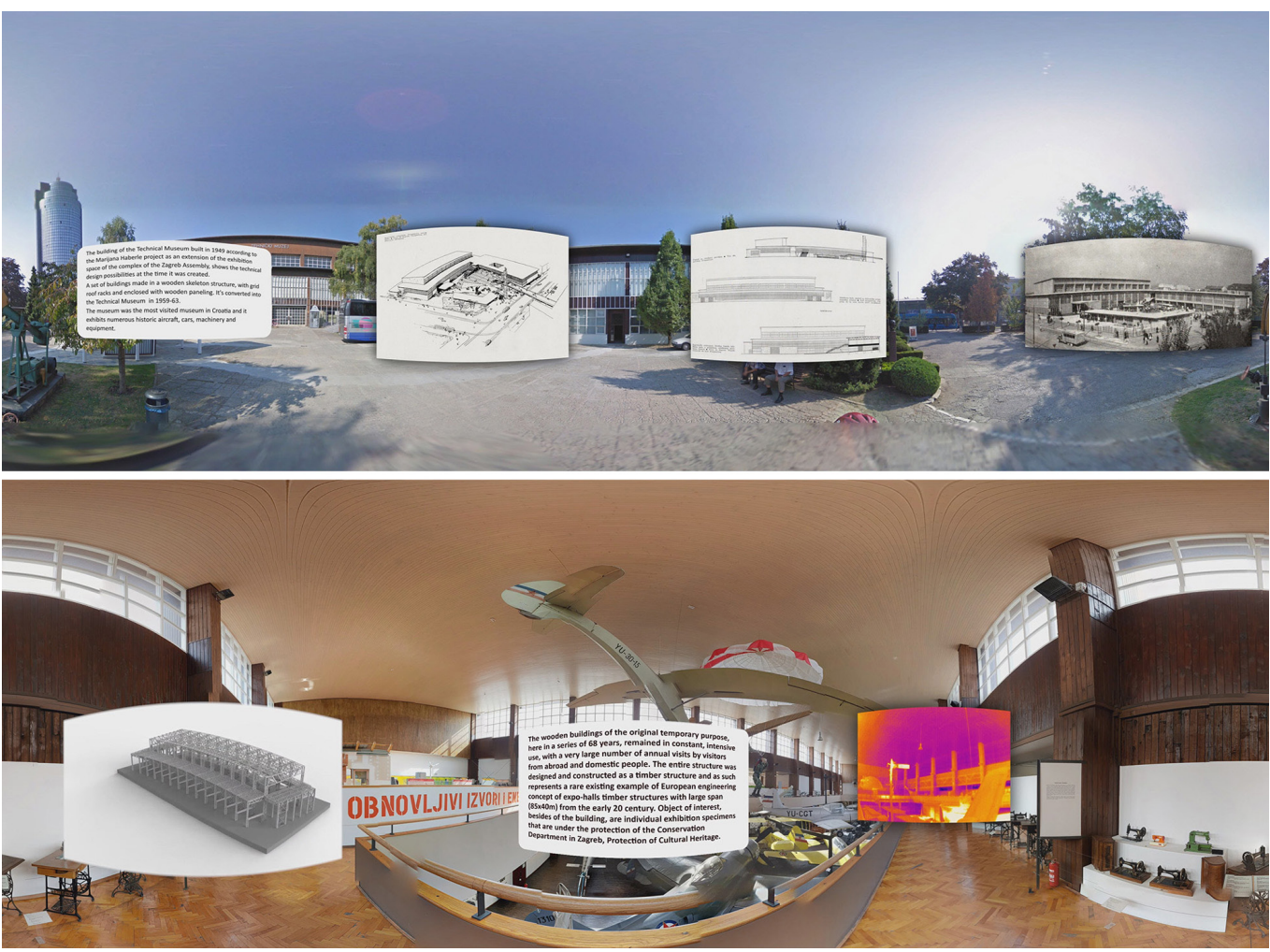

\section{Conclusions and future developments}

The complex, built in 1949 as a temporary structure, was built at a time when cross-laminated timber was almost unknown, making this building a project of absolute interest, where ambition and audacity of the designer still impresses today. The imposing wooden structure is a valuable example of Croatian post-war architecture, and in 2005 it was included in the protected cultural heritage.

Despite this, the architecture of the Tesla Museum was still poorly investigated before this project. The modern BIM surveying and modelling techniques implemented have not only made it possible to understand, preserve and manage the artefact but have also become the basis for communicating this value. New media such as the web and virtual reality and augmented reality tools therefore become lexical tools for dialogue and storytelling for the new generations, opening up to subsequent reuse in a logical cross-generational communication and cultural transfer. 


\section{Notes}

[I] Experimentation carried out within the European project "INCEPTION - Inclusive Cultural Heritage in Europe through 3D semantic modelling", concluded in May 2019 and funded by the European Commission under the Horizon 2020 Programme, Research and Innovation Action under Grant Agreement No. 665220.

[2] Technical Museum website in Nikola Tesla: <tmnt.hr/hr-hr>

[3] Referable to a LOD F/G provided for by the Italian legislation UNI | I337-4:20 I7 for works of historical-architectural interest.

[4] A specific set of properties allows you to extend the IFC $2 \times 3$ standard and include component nomenclatures according to the Getty vocabulary, through specific addressing of the INCEPTION platform via links.

\section{References}

Ausonio Elena, Battini Carlo, Fagandini Roberta, Federici Bianca et al. (2018). Potenzialità dei software Free e/o Open Source per la modellazione, gestione e fruizione di entità 3D. In Geomatics Workbooks, n. I4 - FOSS4G-it.

Bonsma Peter, Bonsma Iveta, Ziri Anna Elisabetta, ladanza Ernesto et al. (20I8). Handling huge and complex 3D geometries with Semantic Web technology. In IOP Conference Series: Materials Science and Engineering, vol. 364, No. I, pp. I2-4I.

Brusaporci Stefano, Ruggieri Gianfranco, Sicuranza Filippo, Maiezza Pamela (20 I 7). Augmented Reality for Historical Storytelling. The INCIPICT Project for the Reconstruction of Tangible and Intangible Image of L'Aquila Historical Centre. In Proceedings, I. 1083

Cadelano Gianluca, Cicolin Francesco, Emmi Giuseppe, Mezzasalma Giulia et. Al. (2019). Improving the Energy Efficiency, Limiting Costs and Reducing CO2 Emissions of a Museum Using Geothermal Energy and Energy Management Policies. In Energies 2019, 12, 3192.

Di Giulio Roberto, Maietti Federica., Piaia Emanuele, Medici Marco et al. (2017). Integrated data capturing requirements for 3D semantic modelling of Cultural Heritage: the INCEPTION protocol. In Int. Arch. Photogramm. Remote Sens. Spatial Inf. Sci., XLII-2/W3, 25I-257.

Fatta Francesca, Bassetta Manuela, Manti Andrea (2017). Survey Methodologies, Research and Technological Innovation for a Case of Medieval Archaeology: Torre Melissa in the province of Crotone. In DisegnareCon I0(19), 6-I.

Maietti Federica, Di Giulio Roberto, Medici Marco, Ferrari Federico et al. (2020). Documentation, Processing, and Representation of Architectural Heritage Through 3D Semantic Modelling: The INCEPTION Project. In Bolognesi Cecilia, Santagati Cettina (eds.). Impact of Industry 4.0 on Architecture and Cultural Heritage. Hershey, PA: IGI Global, pp. 202-238.

Nex Francesco, Remondino Fabio (20 I4). UAV for 3D mapping applications: a review. In Applied geomatics, 6(I), I- I 5.

Parrinello Sandro, Picchio Francesca, Bercigli Monica (2016). La 'migrazione' della realtà in scenari virtuali: Banche dati e sistemi di documentazione per la musealizzazione di ambienti complessi. Musei virtuali dell'architettura e della città. In Disegnarecon, 9(17), |4- |

Rajčić Vlatka, Čizmar Dean, Stepinac Mislav (2013). Reconstruction of the Technical Museum in Zagreb. In Advanced Materials Research 778, 919-926.

Rajčić Vlatka, Stepinac Mislav, Barbalić Jure (2019). In Situ Advanced Diagnostics and Inspection by Non-destructive Techniques and UAV as Input to Numerical Model and Structural Analysis - Case Study, In Moropoulou Antonia, Korres Manolis, Georgopoulos Andreas, Spyrakos Constantine, Mouzakis Charalambos (eds.). Transdisciplinary Multispectral Modeling and Cooperation for the Preservation of Cultural Heritage. TMM_CH 2018. Communications in Computer and Information Science, vol 962. Cham: Springer.

Vranić Dubravka (2020).The Zagreb Fair as a Generator of New Zagreb's Planning. In Journal of Planning History.

\section{Authors}

Marco Medici, Università di Ferrara, marco.medici@unife.it

Federico Ferrari, Università di Ferrara, federico.ferrari@unife.it

To cite this chapter. Medici Marco, Ferrari Federico (2020). Rilievo e documentazione del museo Tesla a Zagabria per la valorizzazione mediante applicazioni di AR eVR/ Survey and documentation of the Tesla Museum in Zagreb for the valorisation through AR and VR applications. In Arena A., Arena M., Brandolino R.G., Colistra D., Ginex G., Mediati D., Nucifora S., Raffa P. (a cura di). Connettere. Un disegno per annodare e tessere. Att del $42^{\circ}$ Convegno Internazionale dei Docenti delle Discipline della Rappresentazione/Connecting. Drawing for weaving relationships. Proceedings of the 42th International Conference of Representation Disciplines Teachers. Milano: FrancoAngeli, pp. 24I4-2433. 